\title{
Florivory by lizards on Tacinga inamoena (K.Schum.) N.P.Taylor \& Stuppy (Cactaceae) in the Brazilian Caatinga
}

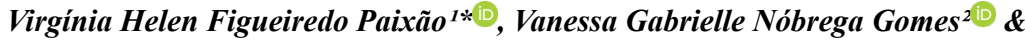 \\ Eduardo Martins Venticinque \\ ${ }^{1}$ Universidade Federal do Rio Grande do Norte, Campus Universitário Lagoa Nova, S/N, Lagoa Nova, \\ 59078-970, Natal, RN, Brasil. \\ ${ }^{2}$ Instituto Nacional do Semiárido, Avenida Francisco Lopes de Almeida, S/N, Serrotão, 58434-070, \\ Campina Grande, PB, Brasil. \\ *Corresponding author: paixaovir@gmail.com
}

PAIXÃO, V.H.F., GOMES, V.G.N., VENTICINQUE, E.M. Florivory by lizards on Tacinga inamoena (K.Schum.) N.P.Taylor \& Stuppy (Cactaceae) in the Brazilian Caatinga. Biota Neotropica 21(2): e20201109. https://doi. org/10.1590/1676-0611-BN-2020-1109.

\begin{abstract}
Florivory can alter plant reproductive success by damaging sexual reproductive structures and disrupting plant-pollinator interactions through decreased flower attractiveness. Here, we report new records of the cactus Tacinga inamoena flower consumption by the Tropidurus hispidus lizard in the Brazilian Caatinga. We monitored 53 flowers from 11 T. inamoena individuals with camera traps over a 1-year period, totalling 450 camera-days of sample effort. We detected four florivory events. In three of these events, flowers were entirely consumed or had their reproductive structures severely damaged, leading to no fruit formation. Florivory events occurred in the morning, right after anthesis, in flowers near the ground, and lizards did not climb the cactus. Our results suggest that $T$. hispidus florivory on $T$. inamoena could have a negative impact on fruit set, since the consumed flowers were entirely destroyed. However, the long-term effects of florivory by lizards on T. inamoena reproductive success in the Caatinga still needs to be elucidated.
\end{abstract}

Keywords: Camera traps; Dry forest; Flower herbivory; Plant-animal interactions; Tropidurus hispidus.

\section{Florivoria por lagartos em Tacinga inamoena (K.Schum.) N.P.Taylor \& Stuppy (Cactaceae) na Caatinga brasileira}

\footnotetext{
Resumo: A florivoria pode alterar o sucesso reprodutivo da planta através de danos às estruturas reprodutivas sexuais e interrupção das interações planta-polinizador por meio da diminuição da atratividade das flores. Aqui, relatamos novos registros de consumo de flores da cactácea opuntióide Tacinga inamoena pelo lagarto Tropidurus hispidus na Caatinga brasileira. Nós monitoramos 53 flores de 11 indivíduos de T. inamoena com armadilhas fotográficas por um período de um ano, totalizando 450 dias-câmera de esforço amostral. Detectamos quatro eventos de florivoria. Em três desses eventos, as flores foram totalmente consumidas ou tiveram suas estruturas reprodutivas severamente danificadas, não levando à formação de frutos. Os eventos de florivoria ocorreram pela manhã, logo após a antese, em flores próximas ao solo, e os lagartos não escalaram o cacto. Nossos resultados sugerem que a florivoria de $T$. hispidus em T. inamoena pode ter um impacto negativo na frutificação, uma vez que as flores consumidas foram totalmente destruídas. No entanto, os efeitos a longo prazo da florivoria por lagartos sobre o sucesso reprodutivo de T. inamoena na Caatinga ainda precisam ser elucidados.

Palavras-chave: Armadilhas fotográficas; Floresta seca; Herbivoria floral; Interações planta-animal; Tropidurus hispidus.
} 


\section{Introduction}

Florivory refers to the consumption of floral structures by a wide variety of animal taxa (McCall \& Irwin 2006). It can decrease plant reproductive success by damaging floral sexual structures or altering flower availability and attractiveness to pollinators (Cascante-Marín et al. 2009; Carper et al. 2016). Vertebrate florivory distinguishes from invertebrate florivory since entire flowers are frequently eaten in the former (Riba-Hernandez \& Stoner 2005). Such is the case of florivory by lizards, as their feeding on flowers is often destructive (Olsson et al. 2000). Many lizard species feed on nectar and other flower parts because of their high nutritional and energetic values, potentially playing a significant positive role in pollen transfer (Pérez-Mellado \& Casas 1997; Gomes et al. 2013; Hervías-Parejo et al. 2020).

Cactaceae Juss. is one of the most diverse plant families in the Neotropics, representing an important floristic element in arid and semiarid environments with extreme conditions (Mutke 2015). For this family, florivory has been found in drier areas, where cacti flowers stand out for their water content and nutritional value (Nobel 2002). In such environments, cacti flowers are partially or entirely consumed by invertebrates, e.g., Opuntia Mill. flowers eaten by Lepidoptera larvae in Chihuahuan Desert (Pinã et al. 2007, 2010), Ariocarpus Scheidw. flowers consumed by Coleoptera and Lepidoptera in Mexico (CárdenasRamos \& Mandujano 2019), destruction of flower parts (tepals, stamens, stigma) of Melocactus Link \& Otto (Colaço et al. 2006) and Cereus Mill., Pilosocereus Byles \& Rowley, Harrisia Britton, and Tacinga Britton \& Rose (Rocha et al. 2020) by flower-damaging bees Trigona spinipes (Fabricius 1973), and vertebrates, e.g., Opuntia flowers eaten by lizards in Galápagos Island (Nobel 2002), Melocactus flowers eaten by Tropiduridae lizards in the Brazilian Caatinga (Gomes et al. 2013), and the short columnar cactus Echinopsis rhodotricha K.Schum. florivory by deer and peccaries in the Brazilian Chaco (Gomes et al. 2016).

Tacinga is a genus of the subfamily Opuntioideae, composed of eight species endemic from Brazil, restricted to the semiarid lands in the Eastern corner of the country (Zappi \& Taylor 2020). Tacinga inamoena (K.Schum.) N.P.Taylor \& Stuppy, commonly known as "cumbeba" or "quipá", is a subshrub cactus, with round to oblong pads and solitary subapical flowers at the top of the branches, 4-6 $\times 3.5-4 \mathrm{~cm}$, with a green globose pericarpel, $10 \mathrm{~mm}$ and orange-red, acute, fleshy bract-scales subtending bristles (Taylor \& Zappi 2004; Peixoto et al. 2016) (Figure 1a). Their flowers, which are the showiest of the genus, are large, shiny, have erect stamens forming a column surrounding the stigma, provide pollen and nectar as floral rewards, and are pollinated by hummingbirds (Lambert 2009). The flowering period starts at the end of the rainy season, continues throughout the dry season, peaking in September/October (Quirino 2006). Flower anthesis is diurnal, usually lasting one day, from eight to 11 hours in prickly pears, and sometimes opening on a second day (Pimienta-Barrios \& del Castillo 2002).

Tropidurus hispidus (Spix, 1825) is a heliophilous lizard that can reach up to $35 \mathrm{~cm}$ in total length, the largest of the genus (Kolodiuk et al. 2010). It is widely distributed in South America, occurring in open landscapes such as Caatinga, and living in forest borders, rocky outcrops, and human-altered areas (Fialho et al. 2000). Its generalist diet comprises plant material, ants, insect larvae, and vertebrates. Plant material (e.g., leaves, non-identified flowers, and fruits) have been reported as one of the three most important food items for $T$. hispidus populations in Caatinga and in rocky outcrops areas, especially

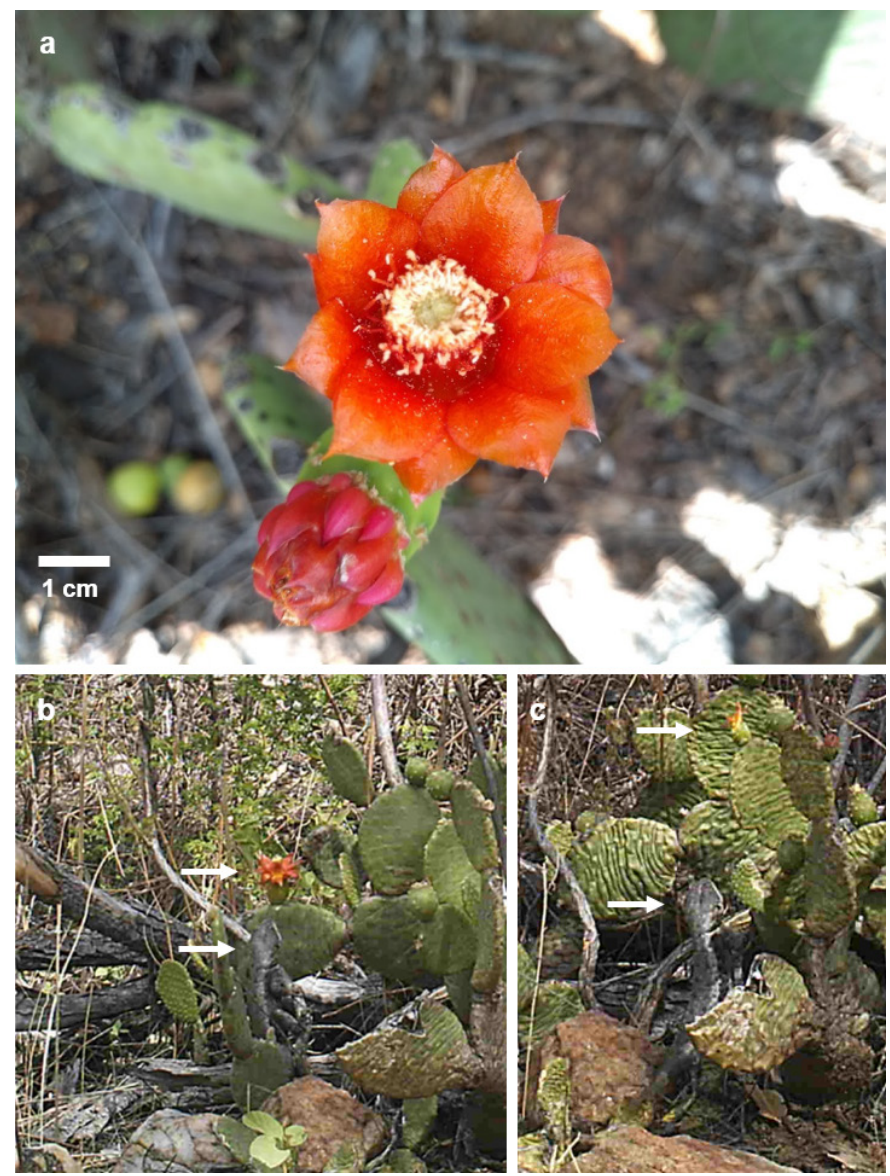

Figure 1. a) Tacinga inamoena flower, (b-c) Tropidurus hispidus looking at an entire and partially eaten flower, respectively.

during the dry seasons (Van Sluys et al. 2004, Kolodiuk et al. 2010; Albuquerque et al. 2018), yet little is known about the identity of the plant species consumed (Koski et al. 2018).

During a study about Cactaceae frugivory by vertebrates in the Caatinga, a seasonally dry tropical forest in northeastern Brazil, we recorded florivory events by lizard Tropidurus hispidus on the cactus Tacinga inamoena. Herein, we quantified and described this flower herbivory interaction, which is new information for both species.

\section{Material and Methods}

Our study site was the Santo Antônio Ranch private property located in Lajes municipality ( $05^{\circ} 47^{\prime} 48^{\prime}$ ' S, 36 $6^{\circ} 14^{\prime} 23^{\prime}$ ' W), Rio Grande do Norte state, northeastern Brazil (Brazilian Semiarid region). The region is characterized by low irregular rainfall ( $>300 \mathrm{~mm} /$ year), long periods of drought, and high average annual temperatures $\left(30^{\circ} \mathrm{C}\right)$. We monitored 53 flowers from $11 \mathrm{~T}$. inamoena individuals using camera traps (Bushnell Trophy CAM 8 MP HD) from September 2018 to July 2019. We had a total of 450 camera-days of sample effort distributed throughout the months (on average 45 cameradays per month). We placed the cameras one to two meters away from the flowering individuals and configured it to capture two photos followed by 10 second videos, in intervals of one minute. We then left the cameras in the field working 24 hours/day every month, recording the whole anthesis period of blooming flowers. We chose plants that were located at least 70 $\mathrm{m}$ from each other to ensure spatial heterogeneity. 
We categorized the flower consumption records into four categories (from four to one) according to the Damage Intensity (D.I.) caused by the lizard on the flower. In the fourth category, the flower was entirely consumed (flower and pericarpel, which could be entirely consumed or detached from the plant); in the third category, the flower was entirely consumed and pericarpel was damaged; in the second category, the flower was entirely consumed without damaging the pericarpel, and in the first category, the flower was partially consumed, without damage to the pericarpel. Each record was classified into the four categories by analyzing the photos and videos. Day and time of consumption as well as the height of flowers consumed were also recorded.

\section{Results}

Tropidurus hispidus ate four T. inamoena flowers, which corresponded to $7.5 \%$ of the flowers monitored in the study period $(\mathrm{N}=53)$. Three of the florivory events happened in the same cactus individual at the end of the 2018 dry season, and the other one during the 2019 rainy season (Table 1). All the florivory events occurred in the morning, right after anthesis, during single visits that, in some cases, lasted several minutes (Table 1). In the last florivory event we recorded, the flower started anthesis on one day and opened again on a second day, when it was then fully eaten by the lizard. However, we did not record flower visitors on this flower during its first day of anthesis.

Lizards approached the plant and started gradually eating the flowers located near the ground, eventually leaning on wooden sticks on the ground to avoid climbing the cactus, and began by tearing the petals until reaching the globose pericarpel (Table 1, Figure 1). In one of the events, the lizard jumped to finish consuming the globose pericarpel remains (Video).

In three florivory events, the flowers were either entirely consumed $(\mathrm{N}=2$, D.I. $=4)$, including petals, stamens, and stigma along with the globose pericarpel, or severely damaged $(\mathrm{N}=1$, D.I. $=3$ ) (Table 1$)$. No fruits developed in these damaged flowers. In only one of the events, the petals were not completely consumed and the pericarpel was not damaged (D.I. $=1$ ), remaining attached to the plant for more than 34 days until we collected the camera. In this case, we cannot affirm whether this flower developed into a fruit, considering that T. inamoena fruits take an average of six months to ripen after fertilization (Quirino 2006). As we observed in the footage, T. inamoena buds took about 25 days to develop and start anthesis, remaining open for a day or sometimes opening a second day. Throughout the monitored months, other available structures (e.g. flower buds and ripe and/or unripe fruits) were not consumed.

\section{Discussion}

Florivory can greatly impact plant species, similar to or sometimes more than tissue herbivory (McCall \& Irwin 2006). Flower herbivores can indirectly interfere in plant reproductive success by damaging the petals, making the flower unrecognizable or less attractive to pollinators (Krupnick \& Weis 1999; Mothershead \& Marquis 2000). In turn, this can affect the sexual display of the plant and disrupt plant-pollinator mutualistic interactions (Krupnick et al. 1999; Leavitt \& Robertson 2006). In general, petal removal can indirectly decrease reproductive output (seed set) via decreased flower visits by pollinators (Leavitt \& Robertson 2006; Carper et al. 2016; Tsuji \& Ohgushi 2018).

In one of the florivory events recorded on T. inamoena, the petals were not entirely consumed by the lizard T. hispidus, and, although through the camera traps we could not determine whether the reproductive structures were damaged or not, we did not observe any flower visitors after consumption by the lizard. In the prickly pear Opuntia microdasys (Lehm.) Pfeiff., florivory by Lepidoptera larvae caused a substantial decrease in their reproductive success by destroying the plant reproductive structures (Pinã et al. 2010). Also, florivory by Lepidoptera larvae on $O$. microdasys floral buds caused a high percentage of abortion and, consequently, no fruits (Pinã et al. 2007). In E. rhodotricha, a short columnar cactus species from the Brazilian Chaco, flowers that were partially damaged by deer and peccaries did not set fruits (Gomes et al. 2016). In contrast, flowers of the globular cactus Melocactus ernestii Vaupel also had their petals consumed by Tropiduridae lizards. However, such florivory did not impact the plant reproductive success, probably because the flower reproductive structures of Melocactus species are protected inside a modified stem (cephalium) and M. ernestii is capable of self-pollination (Gomes et al. 2013).

It is expected that bigger animals such as vertebrates would remove the entire flower when feeding on this resource (Riba-Hernandez \& Stoner 2005; Gomes et al. 2016). In this case, florivory can have a direct effect on the plant reproductive output because completely removing the flower takes away its chances of reproducing developing fruit (McCall \& Irwin 2006; Cascante-Marín et al. 2009). This pattern has been observed in E. rhodotricha florivory by deer and peccaries (Gomes et al. 2016) and in this present study. In our records, in three of the four florivory events, $T$. inamoena flowers were severely damaged.

Lizards and cactus flowers appear to have an old relationship, especially Iguania lizards and prickly pear cacti on islands (Christian \& Tracy 1982; Christian et al. 1984; Schluter 1984). A study about the diet of the Tropiduridae lizard Microlophus pacificus (Steindachner 1876) on Isla Pinta Galápagos found Opuntia flowers in its stomach and a positive correlation between lizard body size and herbivory (Schluter 1984), followed by a recent study that has observed $M$. pacificus consuming Opuntia galapageia Hensl. flowers in the field, possibly transporting its pollen and acting as a pollinator (Hervías-Parejo et al. 2020). Opuntia florivory by a non-insular lizard species of Cnemidophorus was first

Table 1. Florivory on Tacinga inamoena at a Caatinga site in Lajes municipality, Rio Grande do Norte state, northeastern Brazil. Day of flower anthesis, day of flower consumption by Tropidurus hispidus lizard, time of consumption (start and end time), and height of the flower consumed (m). Damage intensity of the florivory and geographic location of the cactus consumed.

\begin{tabular}{lcccccc}
\hline Anthesis & Consumption & Start & End & Flower height & Damage intensity & Location \\
\hline $11 / 15 / 2018$ & $11 / 15 / 2018$ & $08: 42$ & $09: 22$ & 0.3 & 4 & $05^{\circ} 47^{\prime} 48.4^{\prime} \mathrm{S}, 036^{\circ} 144^{\prime} 23.8^{\prime \prime} \mathrm{W}$ \\
$11 / 29 / 2018$ & $11 / 29 / 2018$ & $08: 09$ & $08: 20$ & 0.6 & 3 & $05^{\circ} 47^{\prime} 48.4^{\prime} \mathrm{S}, 036^{\circ} 144^{\prime} 23.8^{\prime \prime} \mathrm{W}$ \\
$12 / 26 / 2018$ & $12 / 26 / 2018$ & $09: 01$ & $09: 03$ & 0.4 & 1 & $05^{\circ} 47^{\prime} 48.4^{\prime} \mathrm{S}, 036^{\circ} 144^{\prime} 23.8^{\prime \prime} \mathrm{W}$ \\
$04 / 15 / 2019$ & $04 / 16 / 2019$ & $10: 44$ & $10: 45$ & 0.1 & 4 & $05^{\circ} 47^{\prime} 52.4^{\prime} \mathrm{S}, 036^{\circ} 144^{\prime} 21.3^{\prime \prime} \mathrm{W}$ \\
\hline
\end{tabular}


recorded at Paraguand Peninsula, Venezuela, where C. lemniscatus (Linnaeus 1758) was seen eating Opuntia wentiana (Britton \& Rose) petals (Mijares-Urrutia et al. 1997). In this last case, flowers were located near the ground and the lizard did not have to climb the cactus.

Opuntioideae cacti offer a great amount of resources including cladodes, fruits, and flowers (Mellink \& Riojas-López 2002). A common reproductive feature of cacti is asynchronous flower development, which is, many floral buds, flower at anthesis, and unripe fruits available at the same time (Pimienta-Barrios \& Nobel 1995; Pimienta-Barrios \& del Castillo 2002; Quirino 2006). Despite that, two-thirds of reptiles that consume platyopuntias on the Galápagos Islands specifically eat their flowers, probably because of the pollen and nectar of cacti, which are often rich in sucrose (Pimienta-Barrios \& del Castillo 2002; Fleming et al. 1994). Similarly, when feeding on T. inamoena flowers in anthesis, T. hispidus lizards ignored flower buds and ripe or unripe fruits.

Tacinga flowers have erect stamens and showy colours, such as the orange-red T. inamoena flowers, which have evolved to be pollinated by hummingbirds (Lambert 2009). Lizards use their vision to search for food near the ground and some diurnal species may also have visual pigments and photoreceptors, similar to those in birds, which could help them detect food (Ellingson et al. 1995; Janzen \& Brodie 1995). Such features may have favoured T. inamoena flower detection by Tropiduridae lizards, as these flowers are located near the ground ( $=0.35 \mathrm{~m}$ in height, according to Table 1). Also, T. inamoena flower anthesis starts in the morning, overlapping with $T$. hispidus activity patterns, which is also when flowers are most conspicuous and provide copious amounts of nectar $22 \pm 1.8 \mu 1[\%]=26 \pm 1.0(\mathrm{~N}$ $=5$ flowers), corresponding to $6.3 \pm 0.5 \mathrm{mg}$ sugar per flower (Galetto \& Bernadello 2005).

Some lizards search for plant material mainly during dry periods in environments with high temperature and low water availability (Koski et al. 2018). Vitt (1995) reported the lizards Tropidurus hispidus, Tropidurus semitaeniatus (Spix 1825), and Salvator merianae (Duméril \& Bibron 1839) feeding on plant material in the Caatinga. Other examples of plant consumption by lizards includes Tropidurus pinima (Rodrigues 1984) feeding on cactus fruits and seeds and nonidentified flowers (Xavier \& Dias 2017), Ameivula ocellifera (Spix 1825 ) consumption of flowers of Cassia L. sp., Tropidurus torquatus (Wied-Neuwied 1820), which flowers comprise an important part of its diet (Rocha \& Bergallo 1994), Tropidurus psammonastes Rodrigues, Kasahara and Yonenaga-Yassuda 1988 consumption of non-identified flowers (Lima \& Rocha 2006), and Liolaemus lutzae Mertens 1938 consuming flowers of Ipomoea litorallis (L.) Boiss. (Rocha 1991).

According to Albuquerque et al. (2018) flower eating by T. hispidus was observed in populations of Caatinga and Cerrado, being higher during water scarcity periods in dryer areas. Tropidurus hispidus searches for floral food resources due to its need for water, as well as the high nutrient contents of flowers. The peak flowering of T. inamoena occurs in the dry season (Quirino 2006). Thereby, its flowers are an important resource for lizard energy requirements, especially in an environment as the Caatinga, where water and food resources are scarce in the dry months, which can last for a long part of the year. Despite this plant-animal interaction could bring negative impacts to the plant reproductive output, additional investigation is needed to evaluate the long-term effects of florivory by lizards on $T$. inamoena populations and whether it can influence its reproductive success by reducing the fruit and seed set.

\section{Acknowledgments}

We thank João Bernardino for help in data collection in the field, Eugenia Schmidt, Juan Carlos, Fernanda Lamin, and Paulo Marinho for logistic support and equipment. Adrian Garda and Daniela Zappi for identification of lizard and cactus species, respectively. We thank INSA for the financial support. This study was financed in part by the Coordenação de Aperfeiçoamento de Pessoal de Nível Superior - Brasil (CAPES) - Finance Code 001. EMV (308040/2017-1) and VGNG (301272/2020-4) were supported by Conselho Nacional de Desenvolvimento Científico e Tecnológico (CNPq).

\section{Author Contributions}

Virgínia Helen Figueiredo Paixão: Substantial contribution in the concept and design of the study; Contribution to data collection; Contribution to data analysis and interpretation; Contribution to manuscript preparation.

Vanessa Gabrielle Nóbrega Gomes: Contribution to manuscript preparation; Contribution to critical revision, adding intelectual content.

Eduardo Martins Venticinque: Substantial contribution in the concept and design of the study; Contribution to data collection; Contribution to data analysis and interpretation.

\section{Conflicts of Interest}

The author(s) declare(s) that they have no conflict of interest related to the publication of this manuscript.

\section{References}

ALBUQUERQUE, R.L., PROTÁZIO, A.S., CAVALCANTI, L.B.Q., LOPEZ, L.C.S. \& MESQUITA, D.O. 2018. Geographical ecology of Tropidurus hispidus (Squamata: Tropiduridae) and Cnemidophorus ocellifer (Squamata: Teiidae) in a Neotropical region: a comparison among Atlantic Forest, Caatinga, and coastal populations. J. Herpetol. 52(2):145-155.

CÁRDENAS-RAMOS, D. \& MANDUJANO, M.C. 2019. Florivory effects on pollinator preference and the reproductive output of a threatened living rock cactus, Ariocarpus retusus (Cactaceae). Haseltonia 2018(25):133-139.

CARPER, A.L., ADLER, L.S. \& IRWIN, R.E. 2016. Effects of florivory on plant-pollinator interactions: Implications for male and female components of plant reproduction. Am. J. Bot. 103(6):1061-1070.

CASCANTE-MARÍN, A., WOLF, J.H.D. \& OOSTERMEIJER, J.G.B. 2009. Wasp florivory decreases reproductive success in an epiphytic bromeliad. Plant Ecol. 203(1):149-153.

CHRISTIAN, K.A. \& TRACY, C.R. 1982. Reproductive Behavior of Galápagos Land Iguanas, Conolophus pallidus, on Isla Santa Fe, Galápagos. In Iguanas of the world: Their behavior, ecology, and conservation (G.M. Burghardt \& A.S. Rand, eds.). Noyes Publications, New Jersey, p.366-378.

CHRISTIAN, K.A., TRACY, R.C. \& PORTER, W.P. 1984. Diet, digestion, and food preferences of Galápagos land iguanas. Herpetologica 40(2):205-212.

COLAÇO, M.A.S., FONSECA, R.B.S., LAMBERT, S.M., COSTA, C.B.N., MACHADO, C.G. \& BORBA, E.L. 2006. Biologia reprodutiva de Melocactus glaucescens Buining \& Brederoo e M. pauscispinus G. HEINEN \& R. PAUL (Cactaceae), na Chapada Diamantina, Nordeste do Brasil. Revista Brasil. Bot. 29(2):239-249.

ELLINGSON, J.M., FLEISHMAN, L.J. \& LOEW, E.R. 1995. Visual pigments and spectral sensitivity of diurnal gecko Gonatodes albogularis. J. Comp. Physiol. A 177:559-567.

FLEMING, T.H., MAURICE, S., BUCHMANN, S.L. \& TUTTLE, M.D. 1994. Reproductive biology and relative fitness in a trioecious cactus, Pachycereus pringlei (Cactaceae). Am. J. Bot. 81(7):858-867. 
FIALHO, R.F., ROCHA, C.F.D. \& VRCIBRADIC, D. 2000. Feeding Ecology of Tropidurus torquatus: Ontogenetic shift in plant consumption and seasonal trends in diet. J. Herpetol. 34(2):325-330.

GALETTO, L. \& BERNARDELLO, G. 2005. Rewards in flowers: nectar. In Practical pollination biology (A. DAFNI, P.G. KEVAN \& B.C. HUSBAND, eds). Enviroquest, Canada, p.261-313.

GOMES, V.G.N., QUIRINO, Z.G.M. \& MACHADO, I.C. 2013. Pollination and seed dispersal of Melocactus ernestii Vaupel subsp. ernestii (Cactaceae) by lizards: an example of double mutualism. Plant Biol. 16(2):315-322.

GOMES, V.G.N., KOROIVA, R. \& ARAUJO, A.C. 2016. Vertebrate florivory on the short-columnar cactus Echinopsis rhodotricha K. Schum. in the Brazilian Chaco. Plant Ecol. 217(12):1481-1487.

HERVÍAS-PAREJO, S. NOGALES, M., GUZMÁN, B., TRIGO, M.M., OLESEN, J.M., VARGAS, P., HELENO, R. \& TRAVESET, A. 2020. Potential role of lava lizards as pollinators across the Galápagos Islands. Integr. Zool. 15(2):144-148.

JANZEN, E.J. \& BRODIE, E.D. 1995. Visually-oriented foraging in a natural population of herbivorous lizards (Ctenosaura similis). J. Herpetol. 29(1):132-136

KOLODIUK, M.F., RIBEIRO, L.B. \& FREIRE, E.M.X. 2010. Diet and foraging behavior of two species of Tropidurus (Squamata, Tropiduridae) in the Caatinga of Northeastern Brazil. S. Am. J. Herpetol. 5(1):35-44.

KOSKI, D. A., VALADARES, R. T. \& LIMA, A. F. B. 2018. Fruits in the lizard's menu: consumption of Coleocephalocereus fluminensis (Miq.) Backeb. (Cactaceae) by Tropidurus torquatus (Wied, 1820) (Tropiduridae). Herpetol. Notes 11(1):853-855.

KRUPNICK, G.A. \& WEIS, A.E. 1999. The effect of floral herbivory on male and female reproductive success in Isomeris arborea. Ecology 80(1):135-149.

KRUPNICK, G.A., WEIS, A.E. \& CAMPBELL, D.R. 1999. The consequences of floral herbivory for pollinator service to Isomeris arborea. Ecology 80(1):125-134

LAMBERT, S.M. 2009. Tacinga, the hummingbird pollinated prickly pear. Cactus Succul. J. 81(3):156-161.

LEAVITT, H. \& ROBERTSON, I.C. 2006. Petal herbivory by chrysomelid beetles (Phyllotreta sp.) is detrimental to pollination and seed production in Lepidium papilliferum (Brassicaceae). Ecol. Entomol. 31(6):657-660.

LIMA, A.F.B. \& ROCHA, P.L.B. 2006. Ontogenetic change in plant consumption by Tropidurus psammonastes (Tropiduridae), a lizard endemic to the dunes of the São Francisco River, Bahia, Brazil. R. Bras. Zooc. 8(1):65-75.

MCCALL, A.C. \& IRWIN, R.E. 2006. Florivory: the intersection of pollination and herbivory. Ecol. Lett. 9(12):1351-1365.

MELLINK, E. \& RIOJAS-LÓPEZ, M.E. 2002. Consumption of Platyopuntias by Wild Vertebrates. In Cacti: biology and uses (P.S. Nobel, ed.). University of California Press, California, p.109-123.

MIJARES-URRUTIA, A., COLVÉE, B. \& AREND, A.R. 1997. Sauria: Cnemidophorus lemniscatus (NCN). Herbivory. Herpetol. Rev. 28(2):88-88.

MOTHERSHEAD, K. \& MARQUIS, R.J. 2000. Fitness impacts of herbivory through indirect effects on plant-pollinator interactions in Oenothera macrocarpa. Ecology 81(1):30-40.

MUTKE, J. 2015. Cactus ecology and biogeography. In Biogeography and Biodiversity of Cacti (W. BARTHLOTT, K. BURSTEDDE, J.L. GEFFERT, P.L. IBISCH, N. KOROTKOVA, A. MIEBACH, M.D. RAFIQPOOR, A. STEIN \& J. MUTKE, eds). Shcumannia, Germany, p.13-18.

NOBEL, P.S. 2002. Cacti: biology and uses. 1 ed. University of California Press, California.

OLSSON, M., SHINE, R. \& BA'K-OLSSON, E. 2000. Lizards as a plant's 'hired help': letting pollinators in and seeds out. Biol. J. Linn. Soc. 71(2):191-202.
PEIXOTO, M.R., ZAPPI, D.C., SILVA, S.R., COSTA, G.M. \& AONA, L.Y.S. 2016. Cactus survey at the Floresta Nacional of Contendas do Sincorá, Bahia, Brazil. Bradleya 2016(34):38-54.

PÉREZ-MELLADO, V. \& CASAS, J.L. 1997. Pollination by a Lizard on a Mediterranean Island. Copeia 1997(3):593-595.

PIMIENTA-BARRIOS, E. \& NOBEL, P.S. 1995. Reproductive characteristics of pitayo (Stenocereus queretaroensis) and their relationships with soluble sugars and irrigation. J. Am. Soc. Hortic. Sci. 120(6):1082-1086.

PIMIENTA-BARRIOS, E. \& DEL CASTILLO, R.F. 2002. Reproductive biology. In Cacti: biology and uses (P.S. Nobel, ed.). University of California Press, California, p.75-89.

PINÃ, H., MONTANÃ, C. \& MANDUJANO, M.C. 2007. Fruit abortion in the Chihuahuan-Desert endemic cactus Opuntia microdasys. Plant Ecol 193(2):305-313.

PINÃ, H., MONTANÃ, C. \& MANDUJANO, M.C. 2010. Olycella aff. junctolineella (Lepidoptera: Pyralidae) florivory on Opuntia microdasys, a Chihuahuan Desert endemic cactus. J. Arid. Environ. 74(8):918-923.

QUIRINO, Z.G.M. 2006. Fenologia, síndromes de polinização e dispersão e recursos florais de uma comunidade de Caatinga no cariri paraibano. Tese de Doutorado, Universidade Federal de Pernambuco, Recife.

RIBA-HERNANDEZ, P. \& STONER, K.E. 2005. Massive destruction of Symphonia globulifera (Clusiaceae) flowers by the Central American spider monkeys (Ateles geoffroyi) in a tropical humid forest, Costa Rica. Biotropica 37(2):274-278.

ROCHA, C.F.D. 1991. Composição do habitat e uso do espaço por Liolaemus lutzae (Sauria: Iguanidae) em uma área de restinga. R. Bras. Biol. 51(4):839-845.

ROCHA, C.F.D. \& BERGALLO, H.G. 1994. Tropidurus torquatus (Collared Lizard): Diet. Herpetol. Rev. 25(1):69-69.

ROCHA, E.A., DOMINGOS-MELO, A., ZAPPI, D.C. \& MACHADO, I. C. 2020. Reproductive biology of columnar cacti: are bats the only protagonists in the pollination of Pilosocereus, a typical chiropterophilous genus? Folia Geobot. 54:239-256.

SCHLUTER, D. 1984. Body Size, Prey Size and Herbivory in the Galápagos Lava Lizard, Tropidurus. Oikos 43(3):291-300.

TAYLOR, N. \& ZAPPI, D. 2004. Cacti of Eastern Brazil. 1 ed. Royal Botanical Gardens, London.

TSUJI, K. \& OHGUSHI, T. 2018. Florivory indirectly decreases the plant reproductive output through changes in pollinator attraction. Ecol. Evol. 8(1):2993-3001.

VAN SLUYS, M., ROCHA, C.F.D., VRCIBRADIC, D., GALDINO, C.A.B. \& FONTES, A.F. 2004. Diet, activity and microhabitat use of two syntopic Tropidurus species (Lacertilia: Tropiduridae) in Minas Gerais, Brazil. J. Herpetol. 38(4):606-611.

VITT, L.J. 1995. The ecology of tropical lizards in the caatinga of Northeast Brazil. Occ. Pap. Okl. Mus. Nat. His. 1(1):1-29.

XAVIER, M.A. \& DIAS, E.J.R. 2017. Tropidurus pinima: Saurochory. Herpetol. Rev. 48(1):202-203.

ZAPPI, D.C. \& TAYLOR, N.P. 2020. Cactaceae in Flora do Brasil $2020 \mathrm{em}$ construção. Jardim Botânico do Rio de Janeiro. http://floradobrasil.jbrj.gov. br/reflora/floradobrasil/FB1622 (last access in 03/Jul/2020).

Received: $19 / 08 / 2020$

Revised: 09/03/2021

Accepted: 17/03/2021

Published online: 19/04/2021 